\title{
Højredrejning i den Europæiske Union
}

Af Uffe Østergaard

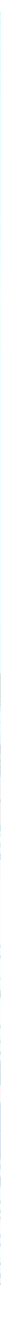


Nationalistiske bevægelser og partier står til voldsom fremgang ved Europaparlamentsvalget 25 . maj. EU har aldrig været specielt populær blandt vælgerne - bortset fra lande som ikke er medlemmer endnu. Der hviler en tung aura af kedsommelighed, fjernhed og centralisme over hele konstruktionen. Kort sagt det modsatte af deltagende demokrati.

Men at højrenationalismen tilsyneladende har så godt et tag i vælgerne, er noget nyt som stiller spørgsmålstegn ved hele samarbejdets legitimitet. Og det på et tidpunkt hvor sammenhold over for udfordringen fra globaliseringen og nu senest Putins Rusland er mere nødvendigt end nogen sinde.

Hvordan er det kommet dertil? Først og fremmest skyldes det at efter godt tres års samarbejde, er EU nu ved at komme tæt på borgerne. På godt, men især på ondt. Det forklarer den unormalt store interesse i medierne for europæiske spørgsmål i denne valgkamp, i Danmark såvel som i det øvrige EU. Det indre marked for arbejdskraft er begyndt at fungere, i hvert fald for de mindre privilegerede arbejdstagere. Arbejdssøgende fra de lande der blev optaget med så stor så stor festivitas i 2004 - og lidt mindre i 2007 - melder sig nu på arbejdsmarkederne og socialkontorerne i de gamle medlemslande, samtidig med at de sydeuropæiske lande kæmper med at komme ud af sparepolitikkens spændetrøje og eksporterer deres bedst uddannede unge til Nordeuropa og Sydamerika.

I 1972 frygtede mange i Danmark at landet ville blive oversvømmet af sydeuropæere - bortset fra de kvinder der glædede sig. Men sydeuropæerne kom aldrig. Tværtimod formindskedes migrationen fra syd til nord i Europa i 1960'erne i kraft af den økonomiske vækst som samarbejdet genererede. Det ændrede sig først med den store østudvidelse i 2004.

I de glade dage før finanskrisen stod danskerne på nakken af hinanden for at lave aftaler med de billige og effektive polske håndværkere. Villakvarterernes glaserede tegl vidner endnu om 00'ernes byggeboom, som i vidt omfang blev muliggjort af billig østeuropæisk arbejdskraft. Men siden har piben fået en anden lyd uden en klar skelnen mellem forbryderbander der er kommet i takt med åbningen af grænserne, og de mange flittige arbejdere der reddede Danmark fra økonomisk overophedning før 2008.

Den konservative Brian Mikkelsen lagde for med at omtale østeuropæerne som "græshopper, der hopper ind på marken, suger al energi ud og derefter hopper videre til næste mark". I debatten om børnecheck til EU-borgere beskrev Venstres formand Lars Løkke Rasmussen de østeuropæiske arbejdere som “ jordbærplukkere, der trækker penge ud af Danmark”. Det er nyt. I årene umiddelbart efter $\mathrm{Mu}$ rens fald var danskerne faktisk et af de lande, som var mest positive over for de østog centraleuropæiske befolkninger. Det har ændret sig nu, især ansporet af at det indre marked for arbejdskraft er ved at indfinde sig med 40-50 års forsinkelse. Det sætter ikke bare den danske velfærdsmodel under pres, men de sociale ordninger i alle de gamle medlemsstater i Nordeuropa. Det er det højredrejningen er en forståelig og logisk reaktion imod.

Selv om retorikken er ved at løbe af sporet i den politiske appel til befolkningens utilfredshed med romaer og jordbærplukkere i Danmark, er substansen i konflikten reel nok. Konsekvenserne af arbejdskraftens frie bevægelighed er bestemt ikke ren mytologi,

Uffe Østergaard er professor i europæisk historie, CBS 
selv om omkostningerne nok overdrives, hvis man skal tro på tallene fra Dansk Industri og Danmarks Statistik. Det er en udvikling som især sætter ufaglærte under hårdt pres. I den forstand er der realiteter bag den stigende utilfredshed. Den tyske kansler Angela Merkel formulerede under et besøg i Storbritannien i foråret problemstillingen præcist med sine udtalelser om at EU skal være et frit arbejdsmarked, men ikke en social union. Det er den sondring og diskussion, man har forsømt -, både herhjemme og i resten af EU.

EU har med en række forordninger og domme fra EU-domstolen bevæget sig i retning af en social union uden egentlig at ville det politisk. Der har været en tro på at de europæiske velfærdsmodeller ville nærme sig hinanden så meget, at der ikke ville være et problem. Men den proces har vist sig at være langt vanskeligere og ikke mindst mere langsommelig end først antaget. Selv om det er østeuropæerne der aktuelt er skydeskive for kreative generaliseringer, hænger det først og fremmest sammen med at det netop er fra disse lande, de største bevægelser af arbejdskraft udgår. I princippet kunne utilfredsheden ligeså godt være rettet mod sydeuropæere. Udfordringen består $i$, at de europæiske socialstater er indrettet meget forskelligt. Og at især de nordiske velfærdsrettigheder kun i princippet er universelle, men reelt indrettet efter og forbeholdt bestemte nationale grupper.

\section{Amerikansk modsætning}

Den aktuelle diplomatiske krise med Rusland og EU's vanskeligheder med at formulere en politik over for situationen i Ukraine har ikke direkte med arbejdsmarkedsproblemerne og højredrejningen at gøre. Alligevel er den med til at udstille EU's enorme udfordringer med østudvidelsen efter murens fald i 1989.

Grundlæggende handler det om en splittelse mellem EU's succes som detailregulerende marked og fiasko som udenrigspolitisk aktør. Hvis man betragter EU som en føderation, er Unionen kendetegnet ved at være det præcis modsatte af den amerikanske føderation. EU er meget stærkt regulerende på en lang række indre områder, men samtidig en svag koalition udadtil, mens USA er det omvendte, en stærk koalition udadtil, militært og udenrigspolitisk, mens det centrale niveau omvendt griber langt mindre ind i de enkelte staters selvstændighed. Hvor den føderale magt i USA forvalter ca. 25 pct. af BNP, råder EU over ca. 1 pct. Men omfanget af detailreguleringen er enormt, som det ses i det kolossale acquis communautaire', som nye lande skal leve op til det. Det er denne detailregulering som får stadig flere borgerlige tilhængere til at blive skeptiske, mens omvendt reguleringsvillige socialister og socialdemokrater bliver stadig mere positive, selv i Danmark.

I forhold til situationen i Ukraine betyder det at EU har om ikke 28 forskellige politikker, så i hvert fald 5-6 forskellige positioner, som er vanskelige at forene. Tyskland repræsenterer af historiske og geopolitiske grunde en konciliatorisk linje over for Rusland, som dels skyldes Anden Verdenskrig, dels afhængigheden af russisk gas. Heroverfor står en række mere konfrontatoriske stater, anført af Polen og den svenske udenrigsminister Carl Bildt, støttet af de baltiske lande som kun kender Rusland alt for godt. Principielt er EU en meget vigtigere aktør over for Ukraine og Rusland end USA pga. den meget større samhandel. Økonomisk set betyder EU mest, men politisk set meget mindre pga. den gensidige afhængighed. De modsatrettede interesser i EU førte i efteråret 2013 til en aktivistisk politik over for Ukraine som blev opfattet som aggressiv af Rusland, men som i realiteten var svag og splittet. Vi ved fra børneopdragelse at det er den dårligst tænkelige model at tale højt og beslutsomt uden at mene det. Det er det EU har gjort med risiko for at man kommer til at betale store summer til Ukraine - der forsvinder i korruption - uden at få garanti for reformer, samtidig med at rus- 
serne bliver rasende, uden at man formår at beskytte Ukraine.

EU's svaghed skyldes den model for samarbejdet som Jean Monnet og andre formulerede med Kul- og Stålunionen og Fællesmarkedet netop for at overvinde modstanden mod suverænitetsafgivelse i nationalstaterne. De modsatrettede interesser udstiller at sikkerhedspolitisk er EU dårlig til at levere. Måske er det gamle kommunistiske lande som Polen der kan bane vejen for en mere selvstændig og handlekraftig europæisk udenrigspolitik. Problemet er Tyskland. Amerikanerne har rigtigt påpeget, at Tyskland både er løsningen og problemet for Europa. Løsningen fordi landet er økonomisk stærkt, problemet fordi det af historiske grunde er politisk svagt. Selv om den udenrigspolitiske dagsorden rummer et uudnyttet potentiale for EU, ikke mindst i forhold til Europas befolkninger som i virkeligheden hellere vil have en stærk sikkerhedspolitisk koalition end massiv detailregulering, er det ikke i den retning udviklingen aktuelt ser ud til at bevæge sig i.

\section{En føderation af nationalstater}

Det er kun ti år siden at skarpe internationale iagttagere som Mark Leonard og Jeremy Rifkin skrev entusiastiske bøger om hvordan EU ville vise vej for verden i det 21. århundrede - underforstået i forhold til mere primitive, magt- og vækstorienterede stater som USA og Kina. Andre fremhævede EU som en stormagt der ikke profilerede sig ved hjælp af traditionel magtpolitik, men i stedet satte standarden for normerne $i$ internationalt samarbejde i en stadig mere global verden. En 'normativ magt' som er overskriften på en artikel af Ian Manners fra RUC. Ganske vist påpegede mere kyniske, primært amerikanske, iagttagere at EU opførte sig sådan, fordi det var for svagt til at gøre andet. Hvis de da ikke ligefrem med en forhenværende amerikansk forsvarsministers ord sagde at EU kunne tage opvasken, efter at de 'rigtige' stormagter havde ordnet tingene og spist middagen. En opfattelse der i juni 2002 blev populariseret i en artikel i tidsskriftet Policy Review af den politiske kommentator Robert Kagan under overskriften, "Europæerne er fra Venus, amerikanerne er fra Mars".

Disse analyser afspejler den generelle svækkelse af Europa i forhold til resten af verden, især BRIK-landene, Brasilien, Rusland, Indien og Kina suppleret med Sydafrika for også at have dette kontinent repræsenteret, Sydkorea, Indonesien, Tyrkiet osv. Men denne svækkelse er en langsigtet tendens der har været undervejs i hele perioden siden Anden Verdenskrig. Først med afkoloniseringen der afsluttedes i midten af 1970'erne, siden den demografiske udvikling der medfører, at de europæiske befolkninger - også i det tidligere kommunistiske Øst- og Centraleuropa - ikke kan reproducere sig selv og bliver stadig ældre. Det har vi vidst længe, men overset i euforien over genforeningen af kontinentet i 2004 og den hysteriske optur i det meste af 00’erne. Først krisen i 2008 har ubarmhjertigt sat spotlys på den strukturelle tilbagegang som er den reelle årsag til nationalismens vækst på højrefløjen, men reelt også på venstrefløjen. Kravet om national suverænitet vil med stor sikkerhed medføre yderligere tab af indflydelse for Europa i verden, selv om nationalisterne kræver det modsatte.

Men der er netop tale om en strukturel tilbagegang, der bedst kan forstås ved en sammenligning med den store forskydning efter 1492, da Europa begyndte at ekspandere på bekostning af resten af verden. Opdagelsesrejser, åbningen af Atlanterhavet og sejlruten til Asien syd om Afrika flyttede det økonomiske centrum fra Middelhavslandene til Nordvesteuro$\mathrm{pa}$, især Nederlandene og England, men også Nordfrankrig og Vesttyskland. Ja selv Østersølandene profiterede af denne omlægning af handelsruterne.

Prisen for den store omlægning af den europæiske økonomi og handelsruterne 
blev betalt af især Italien der havde været førende i middelalderen og renæssancen. Relativt set gik først de italienske bystater og siden Spanien tilbage i forhold til Nordvesteuropa. Men netop relativt set. I flere hundrede år, indtil midten af 1700-tallet, registrerede en stormagt som Venezia ikke sit fald i økonomisk indflydelse. Republikken mistede ganske vist sine græske besiddelser til de osmanniske tyrkere, men bevarede alligevel sin diplomatiske og handelsmæssige rolle. For ikke at tale om det årlige karneval der tiltræk besøgende fra hele Europa. Skal man dømme ud fra det italienske eksempel kan det godt lade sig gøre at miste relativ vægt uden dermed nødvendigvis at gå absolut ned i levestandard.

Det Europa mister i disse år er evnen til at påtvinge resten af verden sine opfattelse og normer. Men det har som sagt været undervejs i mange år. De langsigtede tendenser er næppe forklaringen på den aktuelle krise i EU generelt og eurosamarbejdet specielt, selv om de udgør den historiske baggrund.

\section{Integration efter behov}

På mange måder burde krisen for euroen ikke undre. Ja man kan næsten sige at den var indbygget i konstruktionen af den Økonomiske og Monetære Union fra begyndelsen i december 1991. For trods titlen var der kun tale om en monetær, altså pengepolitisk union, mens det var håbet at den økonomiske union ville indfinde sig hen ad vejen, i takt med at behovet for afgivelse af økonomisk suverænitet blev indlysende for de deltagende regeringer.

Sådan har det europæiske samarbejde med ret stor succes udviklet sig helt siden Kul- og Stålunionen i 1951. Fremgangsmåden hedder i politologisk jargon 'neofunktionalisme' og forbindes med navnet på hjernen bag det europæiske samarbejde, Jean Monnet. Hans i og for sig simple idé var at samarbejde på et forholdsvis begrænset og tilsyneladende uskyldigt områ- de ville nødvendiggøre samarbejde på andre områder. 'Spill over' blev mekanismen døbt af politologen Ernst B. Haas i en epokegørende analyse af Kul- og Stålunionen, "The Uniting of Europe" fra 1958. Den bog blev en bibel for den europæiske integrationsproces og lært udenad af generation efter generation af eurokrater. Jeg har stadig mit godt slidte eksemplar, som jeg læste på Collège d'Europe i Brügge i 1969 sammen med nu glemte tekster om interessegrupper på europæisk plan og stabler af tekniske dokumenter om de landbrugsordninger der blev implementeret netop i de år.

Metoden fungerede fint efter den oprindelige hensigt, nemlig at overvinde modstanden mod forpligtende samarbejde blandt nationale politikere og embedsmænd. Med en sådan succes at disse grupper i dag står sammen, når de mødes $\mathrm{i}$ EU-regi. Her har EU-skeptikerne ret i deres kritik af manglen på 'folkelighed' blandt de ansvarlige. I takt med at de mødes med deres kolleger fra andre lande, sker der en afslibning som virker opdragende på selv de mest krasbørstige kritikere. Et godt eksempel er udviklingen, man fristes til at kalde det civiliseringen, til en tænksom og nuanceret person af en noget usleben politiker som Venstres Jens Rohde, efter at han blev valgt til Europaparlamentet. Men selv en inkarneret og veltalende modstander af EU som Morten Messerchmidt fra Dansk Folkeparti kan forfalde til at råbe på intervention fra $\mathrm{EU}$ når det $\mathrm{fx}$ gælder lovindgreb mod blokade af virksomheder - som fx Vejlegården i 2012 - som led i kampene på det danske arbejdsmarked

Der hvor den neofunktionalistiske integrationsmetode har fungeret mindre heldigt er i forhold til befolkningerne, der i deres naivitet har troet at når politikerne talte om skabelse af et indre marked for varer og arbejdskraft, så handlede det 'kun' om disse områder. At det er umuligt at begrænse markedet på denne måde, behøver man ikke at studere EUdomstolens afgørelser længe for at finde ud 
af. Den har på baggrund af domme fra 1962 og 1963 udviklet et helt sæt af rettigheder på EU-plan, fordi det er umuligt at tale om arbejdskraftens fri vandring uden at det også gælder arbejdskraften som mennesker, deres familie, og arbejdere under uddannelse eller sågar uden arbejde.

I princippet er der ingen ende på implikationerne af det indre marked, som ret beset er et altomfattende revolutionært princip i forhold til staternes suverænitet. At det ikke var underskrivernes hensigt med Rom-traktaten i 1957, ændrer ikke ved følgerne af de principper de enedes om. Det var det de danske socialdemokrater erkendte efter den danske folkeafstemning i 1986 om the European Single Act - i Danmark kaldet 'EF-pakken'”. Poul Schlüter var formentlig i god tro, da han dengang erklærede at med et dansk ja til det indre marked var "Unionen stendød". At det er umuligt at skelne på denne måde erkendte socialdemokraterne, der havde været imod, men efter befolkningsflertallets ja svingede rundt og erstattede deres modstand mod EF med et ja til mere forpligtende politisk samarbejde. Det er en logisk og sammenhængende analyse, som imidlertid har vist sig vanskelig at formidle til vælgerne, i Danmark såvel som i resten af EU.

\section{System Monnet}

Det var denne erkendelse som lå bag den tyske grønne udenrigsminister Joschka Fischers tale på Humboldt universitetet i foråret 2000. Her beskrev han fremmedgørelsen af vælgerflertallet i EU under overskriften 'system Monnet'. Det førte ham til at foreslå en forfatning for EU som i klart sprog skulle gøre det klart for vælgerne, hvad samarbejdet går ud på. Projektet lykkedes delvis med den langvarige forfatningsproces, 'konventet', der resulterede i en tekst hvis første del faktisk beskrev det europæiske samarbejde ret klart og præciserede borgernes rettigheder.

At det ikke var en almindelig forfatning fremgik af titlen, en "traktat om en forfatning for EU”, og mængden af detaljerede paragraffer de sidste mange hundrede sider. Mere logisk end før, men stadig med en uoverskuelig mængde af detaljeret regulering, fordi EU basalt set er et samarbejde mellem suveræne - og mistænksomme - stater. Derfor var det folkeretsligt en traktat, nu blot om en forfatning. Alt dette var klart for de indviede, men blev ikke forstået og derfor afvist af vælgerne i Nederlandene og Frankrig i 2005. Derefter var forfatningen stendød og blev efter en del trakasserier i 2009 erstattet af Lissabontraktaten, der repræsenterer alt det værste og mest uoverskuelige ved EU med en ophobning af detaljerede paragraffer i tilfældig rækkefølge. Rettigheder og europæiske symboler er bevidst udeladt. Dog var charteret om rettigheder allerede vedtaget på et tidligere topmøde, så det gælder alligevel uden at vælgerne har fået det at vide.

Maastricht-traktaten i 1991 var et beslutsomt spring ud i det blå, i stil med proklameringen af et fælles marked i 1957. Reelt var Rom-traktaten kun en toldunion der blev markedsført som et fælles marked. Men med formuleringer og mekanismer som den europæiske domstol der i 1960'erne lagde grunden til de vidtgående rettigheder for arbejdstagere, som er blevet til forpligtende menneskerettigheder og domsafsigelser med forret i forhold til national lovgivning og direkte anvendelse i medlemslandene. Det blev styrket da Kommissionen under Jacques Delors i 1985 relancerede det europæiske samarbejde i form af det indre marked.

Det var samme tankegang der lå bag formuleringen af ØMUen i 1991. En økonomisk union havde været under planlægning lige siden Werner-planen i 1970. Men efter kommunismens sammenbrud i 1989 og genforeningen af Tyskland krævede den franske præsident Francois Mitterrand magt over den tyske økonomi for at modvirke at det nye store Tyskland skulle blive 
alt for dominerende i EU via sin stærke valuta. Deraf forslaget om euroen. Ironisk har den halvhjertede valutaunion netop resulteret i tysk dominans som vi oplever det nu. Men det havde hverken Mitterrand eller den tyske kansler Helmut Kohl forudset da de pressede den fælles valuta igennem kun forsynet med uforpligtende krav til den fælles økonomiske politik. Krav, som hvis de var blevet overholdt, muligvis havde forskånet os for eurokrisen. Men da de første lande der overtrådte de fælles regler om et budgetunderskud på højst 3 pct. og højst 60 pct. gæld var Tyskland og Frankrig, stod ladeporten åben for de sydeuropæiske lande der aldrig havde været i nærheden af at kunne eller at ville - overholde kravene.

I stedet fik vi det lånefinansierede boom i 00'erne. Det skjulte behovet for at tage det næste logiske skridt til en økonomisk forpligtende union som ligger i den neofunktionalistiske samarbejdsmetode, Fischers 'system Monnet'. Det kommer nu efter krisen med katastrofale følger for befolkningerne i de ramte lande og med deraf følgende udfordringer til de politiske systemer og svækkelse af EU's legitimitet i omverdenens og befolkningernes øjne.

Alt det var allerede forudset i 1991, og rygter siger at Jacques Delors var lige ved at smide hele Maastricht-aftalen på gulvet i frustration over dens mangel på konsekvens og logik. Men han beherskede sig i tiltro til at 'system Monnet' endnu engang ville virke og hurtigt overbevise de involverede om nødvendigheden af en tæt koordinering af den økonomiske politik, når man havde faet en fælles valuta. Det er ved at ske nu med den halvhjertede bankunion og overvågning af den økonomiske politik i medlemslandene - med enorme menneskelige omkostninger for Europas unge og uoverskuelige politiske følger. For slet ikke at tale om følgerne for EU's indflydelse i verden, hvor enhver tale om 'normativ magt' nu mest fremkalder rå latter eller hånlige skuldertræk som hos Vladimir Putin.
Det er trist og kræver en grundlæggende nytænkning det europæiske samarbejde. Men næsten værre er at krisen har blotlagt EU's grundlæggende karakter af at være et samarbejde mellem suveræne stater. Det ses i forskydningen fra Kommission og Parlament til det Europæiske Råd og især Euro-gruppen, hvor regeringscheferne mødes. Og her er størrelse afgørende som det altid er tilfældet, når samarbejdet foregår på såkaldt 'mellemstatslig' basis. Det kender vi kun alt for godt fra den lange periode fra den westfalske fred i 1648 til tiden efter Anden Verdenskrig.

EU er netop enestående som internationalt samarbejde ved ikke at være intermen overnationalt og retligt funderet. Det har givet overproportional indflydelse til små og mellemstore stater der kender reglerne og kan formulere en sammenhængende politik. Men krisesituationer gør det klart hvem der bestemmer, når det skal gå stærkt. Indtil det franske præsidentvalg i maj 2012 talte man ligefrem om 'Merkozy', når den tyske kansler Angela Merkel og den franske præsident Nicolas Sarkozy gik uden for lokalet under møderne og blev enige. Og så bagefter udlagde teksten på vegne af de andre. Reelt var det dog Merkel der bestemte, og Sarkozy der fik lov til at udlægge teksten.

Der har ikke udviklet sig en klar arbejdsdeling mellem den franske præsident François Hollande og Angela Merkel, men det betyder blot at det er blevet helt klart at det Tyskland der svinger den europæiske taktstok.

\section{Ny nationalisme i Europa}

Det forpligtende samarbejde med den retlige forankring i EU-domstolen som udgør det enestående ved EU som politisk organisation har en række utilsigtede følger. Ikke 'blot' i form af den manglende legitimitet i befolkningerne øjne der fører til fremgang for nationalpopulistiske partier i hele Europa, i gamle medlemslande som Nederlandene såvel som blandt de nye $\mathrm{i}$ 
Øst- og Centraleuropa. For slet ikke at tale om Skandinavien og Storbritannien.

En paradoksal side af EU er nemlig at der samtidig med den megen tale om overnationalitet og fælles beslutninger reelt er sket en styrkelse af national identitet, trods de mange dommedagsprofetier om svækkelsen af national selvstændighed. Styrkelsen af nationalismen bemærker man ikke i veletablerede nationalstater som Danmark, Sverige og Storbritannien. For det er vanskeligt at være mere end 100 pct. nationalistisk, selv om der er mange der prøver. Men i andre lande er det let at spore en øget national, for ikke at sige nationalistisk, identifikation. Det gælder såvel i Nederlandene og Finland hvor EU-kritiske populister vinder frem i takt med euro-krisen, som i Viktor Orbáns Ungarn hvor de er ved magten.

Overraskende nok gælder det også i et land som Luxembourg der har været selv indbegrebet af europæisk samarbejde pga. sin position mellem Frankrig og Tyskland. Ja, landet der ikke havde et nationalt sprog men benyttede sig af tysk og fransk, har i kraft af EU - og med EU-støtte - etableret et nationalt sprog, letzeburgisch, som vinder mere og mere frem. Før 1986 var det luxembourgske parlament indbegrebet af europæisk adfærd, idet lovforslag blev fremsat på tysk ud fra den begrundelse at tysk er bedst for fantasien. Og vedtaget på fransk, fordi dette sprog er klarest og derfor bedst til at administrere på. Sådan er det ikke mere. I stedet mudrer flertallet af sted på den tyske dialekt med franske gloser der er grundstammen i letzeburgisch. Det har så den yderligere fordel at udenforstående har svært ved at følge detaljerne, når parlamentet drøfter tekniske detaljer om bankhemmelighed og lignende forudsætninger for den skyhøje levestandard i en befolkning der for en stor dels vedkommende oven i købet består af efterkommere af portugisiske indvandrere - som altså nu taler letzburgisch!

Europa er fortsat nationalt og det kan der være mange fordele ved. Men det gør det ikke lettere at enes om de nødvendige reformer af samarbejdet der er forudsætningen for, at Europa ikke taber yderligere indflydelse i verden. Uden at det er blevet bemærket af skeptikerne, har EU's ledere forsøgt at formulere denne indsigt. 12. september 2012 kaldte Kommissionens formand José Manuel Barroso i sin state of the Union-tale i Europa-Parlamentet fællesskabet for en 'demokratisk føderation af nationalstater'.

De danske medier hæftede sig forudsigeligt nok ved ordet føderation, men der er god grund til at tage det logisk modsigende begreb 'føderation af nationalstater' alvorligt. Det er det tætteste vi kommer på en bestemmelse af EU's karakter, den enestående statsdannelse som Jacques Delors engang kaldte en 'UPO', dvs. et 'uidentificeret politisk objekt'. I politisk teori taler man om en 'sui generis' konstruktion, hvormed blot menes at noget nyt er under dannelse. Ingen ved hvor det europæiske projekt ender, men fremgangen for nationalismen ved parlamentsvalget passer godt i en generel tendens som man kan kalde 'global nationalisme'.

Nationalstaterne er ikke ved at forsvinde, men hvordan de skal samarbejde er til permanent forhandling mellem elite og folk. Opmuntrende er at 70 pct. af de danske vælgere ifølge en opinionsundersøgelse i Jyllands-Posten 26.4. 2014 er positive over for det europæiske samarbejde, samtidig med at de skeptiske over for en lang række konkrete måder dette samarbejde foregår på.

Bortset fra Storbritannien ser EU ud til at være ved at blive almindelig indenrigspolitik og ikke et spørgsmål om for eller imod medlemskab. 